\title{
Why do people migrate? A review of the theoretical literature
}

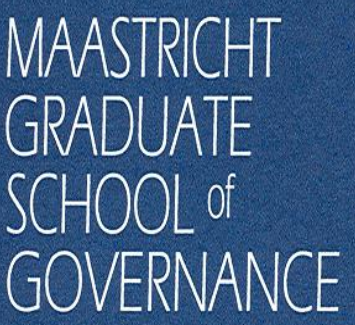

Jessica Hagen-Zanker

Working Paper

MGSoG/2008/WP002

January 2008 


\section{Maastricht Graduate School of Governance}

The 'watch dog' role of the media, the impact of migration processes, health care access for children in developing countries, mitigation of the effects of Global Warming are typical examples of governance issues issues to be tackled at the base; issues to be solved by creating and implementing effective policy.

The Maastricht Graduate School of Governance, Maastricht University, prepares students to pave the road for innovative policy developments in Europe and the world today.

Our master's and $\mathrm{PhD}$ programmes train you in analysing, monitoring and evaluating public policy in order to strengthen democratic governance in domestic and international organisations. The School carefully crafts its training activities to give national and international organisations, scholars and professionals the tools needed to harness the strengths of changing organisations and solve today's challenges, and more importantly, the ones of tomorrow.

\section{Author}

Jessica Hagen-Zanker, PhD fellow

Maastricht Graduate School of Governance

Maastricht University

Email: jessica.hagenzanker@governance.unimaas.nl

I would like to thank Pawel Kaczmarczyk for his helpful comments on an earlier draft of this paper.

\section{Mailing address}

Universiteit Maastricht

Maastricht Graduate School of Governance

P.O. Box 616

6200 MD Maastricht

The Netherlands

Visiting address

Kapoenstraat 2, $6211 \mathrm{KW}$ Maastricht

Phone: +31 433884650

Fax: +31 433884864

Email: info-gov@governance.unimaas.nl 


\begin{abstract}
Massey et al. (1994) is a ground-breaking paper in the migration literature that discusses and unifies different migration theories. However, their review and synthesis is incomplete and fairly brief for researchers interested in a deeper understanding of the migration theory literature. This paper therefore aims to review the complete spectrum of economic migration theory from the 1950s until today and to show the differences and complementarities between the different approaches.
\end{abstract}




\section{Introduction}

Massey et al. (1994) is a ground-breaking paper in the migration literature that discusses and unifies different migration theories. However, their review and synthesis is incomplete and fairly brief for researchers interested in a deeper understanding of the migration theory literature. This paper therefore aims to review the complete spectrum of economic migration theory from the 1950s until today and to show the differences and complementarities between the different approaches.

Migration is the temporary or permanent move of individuals or groups of people from one geographic location to another for various reasons ranging from better employment possibilities to persecution. While migration is as old as humanity itself, theories about migration are fairly new. One of the early writers on modern migration is Ravenstein, who in the 1880 s based his "Laws of Migration" on empirical migration data. This collection of empirical regularities, for example the fact that most migrants only travel short distances, was far from a complete theory of migration. Early migration models (e.g. Zipf, 1946) used the physical concept of gravity and explained migration as a function of the size of the origin and destination population and predicted to be inversely related to distance.

In the 1950s migration theory moved from purely mechanical models to more sophisticated theories. Theoretical predictions of migration flows are first made in the dual-economy models of Lewis in the 1950/60s, in which migration occurs as a result of differences in the supply and demand of labour between the rural and urban sector. The Harris-Todaro models of the 1970/80s augment these models to account for some empirical observations and to make the models specifically about migration. Other macro-theories included the world systems theory and dual-labour market theory, which consider institutions in more detail.

While the early analyses look at aggregate data and often see migration as equilibrating mechanism, the focus since the $1980 \mathrm{~s}$ is on more elaborate microeconomic models. These models analyse individual motivations to migrate, but also consider structural community level factors (e.g. poverty). More modern approaches link the micro and macro level and also include less economic concepts, for example social capital. Another contribution of the more recent literature is the differentiation between causes and perpetuation of migration. The New Economics of Labour Migration developed in the 1980s sees migration as a household decision and 
includes more explanations for migration. This theory will be discussed more extensively. It stands out from the classical theories of migration in that it tries to model the decision-making process more realistically by including a wide range of decision making factors.

We begin this literature review by distinguishing between the different levels of analysis. The most important theories of internal and international migration will be critically discussed in the next sections. While the emphasis is on economic theories, some of them are closely linked to sociological, geographical and anthropological theories. The review will focus on voluntary labour migration, thus disregarding forced migration, family reunion etc. The paper will conclude by unifying the most important theories into one framework.

\section{The level of analysis}

Migration theories can be classified according to the level they focus on. Micro-level theories focus on individual migration decisions, whereas macro-level theories look at aggregate migration trends and explain these trends with macro-level explanations. The meso-level is in between the micro and macro level, e.g. on the household or community level and can explain both causes and perpetuation of migration. Table 1.1 gives an overview of the theories along the level dimensions, whereas table 1.2 gives an overview of the migration theories in terms of their classification as a cause or perpetuation of migration. As will become clear later on, some theories fit into several categories.

Table 1.1. Theories of migration defined by level of analysis

\begin{tabular}{|c|c|c|}
\hline Micro-level & Meso-level & Macro-level \\
\hline $\begin{array}{l}\text { Migration cause: } \\
\text { Individual values/ desires/ } \\
\text { expectancies } \\
\text { e.g. improving survival, } \\
\text { wealth etc. }\end{array}$ & $\begin{array}{l}\text { Migration cause/ } \\
\text { perpetuation: } \\
\text { Collectives/ social networks } \\
\text { e.g. social ties }\end{array}$ & $\begin{array}{l}\text { Migration cause/ } \\
\text { perpetuation: } \\
\text { Macro-level opportunity } \\
\text { structure } \\
\text { e.g. economic structure } \\
\text { (income and employment } \\
\text { opportunities differentials) }\end{array}$ \\
\hline $\begin{array}{l}\text { Main theories: } \\
-\quad \text { Lee's push/ pull factors } \\
-\quad \text { Neoclassical micro- } \\
\text { migration theory } \\
-\quad \text { Behavioural models } \\
-\quad \text { Theory of social systems }\end{array}$ & $\begin{array}{l}\text { Main theories: } \\
-\quad \text { Social capital theory } \\
-\quad \text { Institutional theory } \\
-\quad \text { Network theory } \\
-\quad \text { Cumulative causation } \\
-\quad \text { New Economics of } \\
\quad \text { Labour Migration }\end{array}$ & 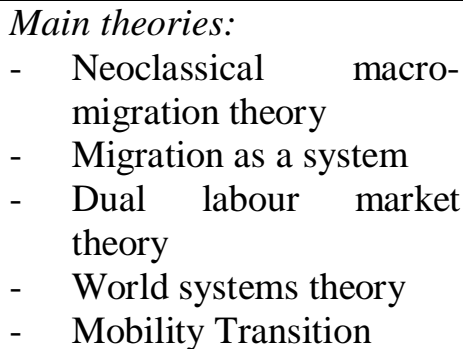 \\
\hline
\end{tabular}

Source: Faist (2000) and own elaboration 
Table 1.2 Theories of migration defined by initiation or perpetuation of migration

\begin{tabular}{|c|c|}
\hline Initiation of migration & Perpetuation of migration \\
\hline $\begin{array}{ll}- & \text { Neoclassical macro-migration theory } \\
- & \text { Migration as a system } \\
- & \text { Dual labour market theory } \\
- & \text { World systems theory } \\
- & \text { Mobility Transition } \\
- & \text { Lee's push/ pull factors } \\
- & \text { Neoclassical micro-migration theory } \\
- & \text { Behavioural models } \\
- & \text { Theory of Social systems } \\
\end{array}$ & $\begin{array}{ll}\text { - } & \text { Migration as a system } \\
\text { - } & \text { World systems theory } \\
\text { - } & \text { Social capital theory } \\
\text { - } & \text { Institutional theory } \\
- & \text { Network theory } \\
\text { - } & \text { Cumulative causation }\end{array}$ \\
\hline
\end{tabular}

Source: Massey et al. (1993) and own elaboration

This paper will discuss the theories in rough chronological order. Therefore first macro-level theories be discussed, followed by micro and meso theories and we will finish the literature review by looking at the perpetuation of migration, which is a fairly new field.

\section{Macro-theories of migration}

The neoclassical macro migration theories explain migration as part of economic development. Internal migration occurs as a result of geographical differences in the supply and demand of labour, mostly between the rural traditional agricultural sector and the urban modern manufacturing sector. The basic model (Lewis, 1954 and Ranis \& Fei, 1961) that grew out of trade theory, assumes perfect markets and a labour surplus in the traditional agricultural sector that is absorbed by the modern sector. The modern sector grows through capital accumulation and by poaching labour from the traditional sector. Rural workers are attracted by the positive wage differential and migrate to the urban sector, i.e. they are pulled to migrate. In these models migration occurs until wage equalisation has occurred.

Todaro and Harris (Todaro, 1969 and Harris \& Todaro, 1970) augmented this model to account for the significant urban unemployment that was found in many less developed countries. Migration is not completely risk-free, because the migrant does not necessarily get a job upon arrival in the city. Rural-urban migration occurs, as long as the expected real income differential is positive. Expected income is a function of the rigid, institutionally determined urban wages and the urban employment rate. Migration costs can be included. The employment rate is the probability of finding a job, i.e. being selected from the pool of labour, which 
increases over time, for example due to wider networks of the migrants. Migration thus increases if urban wages increase or the urban employment rate increases (ceteris paribus). The authors show that it can be perfectly rational to migrate, despite urban unemployment, due to a positive expected income differential. This model has clear predictions and while the significance of income differentials is undisputable in labour migration decision, it is probably not as excessive as Harris and Todaro describe it. The model assumes that an equilibrium will take place, which we do not find in the real world and some of the other empirical predictions e.g. wage equalisation, have also not been found.

The dual labour market theory (Priore, 1979) explains migration as the result of a temporary pull factor, namely strong structural labour demand in developed countries. According to this not purely economic approach, there is economic dualism on the labour market of developed countries and wages also reflect status and prestige. There is a primary sector providing well-paid jobs and a secondary sector, for unskilled jobs, e.g. manufacturing. The demand for migrant labour force stems from several factors. Due to structural inflation, there are constant wage rises in the primary sector. Proportional wage rises in the secondary sector are too expensive; the consequent lower pay makes the secondary sector unattractive to native workers. Migrants are more motivated to work in these low-status jobs, because they do not consider themselves as part of the destination society. Employment in the secondary sector fluctuates according to the economic cycle, making it unstable and uncertain work, again unattractive to native workers. Traditional sources of labour in the secondary sector, women and teenagers are not available anymore due to demographic changes. Women have joined the regular labour force and there are smaller teenage cohorts. Therefore there is a strong demand for temporary migrant labour that acts as a pull factor to migration. This model is important because it explains some of the post-war migration trends in Europe and the United States, but the focus is too narrow with only one pull factor being analysed and with no deeper analysis of migrant decision making.

The world systems theory (Wallerstein 1974), which takes a historical structural approach, stresses the role of disruptions and dislocations in peripheral parts of the world, as a result of colonialism and the capitalist expansion of neoclassical governments and multinationals. It thus takes account of structural factors that other 
theories neglect. The capitalist expansion has had profound consequences for migration issues, as not only the capitalist mode of production, but also the culture and stronger transportation, communication and military links penetrate peripheries. Land consolidation, new capitalist farming methods and manufacturing plants have created a socially uprooted population with weakened attachments to their land and more prone to migration. A strong immigrant labour demand in global cities acts as a pull force to migration. According to this theory, migration follows the dynamics of market creation and structure of the global economy, but more individual motivations are not considered. The exact mechanisms of migration are also not clear. Recent examples of this theory are globalisation in general and the transition of Central and Eastern Europe after the fall of Communism.

Another macro-level model explaining rural-urban migration in less developed countries is Mabogunje's (1970) migration as a system model, in which he explains migration as a dynamic spatial process. Aggregate migration flows and interactions are modelled by starting with a pool of rural potential migrants that is affected by various factors in the decision to migrate. The rural control sub-system controls outflows (e.g. family or community norms), the urban control sub-system controls inflows (e.g. through employment agencies), feedback is channelled back to potential migrants and the background environment also affects migration flows (social \& economic conditions, government policies, transport \& communications infrastructure etc.). The environment and sub-systems are constantly changing, also as a result of the migration flows, which makes the system open and dynamic. Other authors (e.g. Kritz \& Zlotnik, 1992) have also emphasised the importance of viewing international migration as an interdependent dynamic system, with own but interlinked systems for sending and receiving countries and feedback and adjustment coming from the migration process itself. It can also be linked to the world systems theory, discussed above. It is important to take note of interactions between different actors and to emphasize the dynamic nature of migration. Nevertheless the migration system models are vague and do not allow concrete prediction of migration trends.

Politics matter in migration theory, as migration laws and thus the right to cross a border legally directly influence migration flows. These laws of nation states are the result of the relative power of different interest groups. They are influenced by profits (thus linking up with Priore's dual labour market theory), national identity, 
considerations of national security and the extent of multiculturalism in the state. In a historical analysis it is important to point out that acquired rights, laws or existing institutions will always influence migration flows, irrespective of economic considerations, like the business cycle (Hollifield, 2000). Globalisation not only affects the demand for labour or facilitates migrant networks, but also leads to loss of border control. Zolberg (1981) argues that it is not just the economic factors that matter in making the structural setting of migration, for example some of the countries that would be considered peripheral in the world systems theory (the Communist countries) chose to do so due to political reasons and political motives also influence migration flows (e.g. of refugees). The political setting is thus an important structural factor in migration decisions.

Zelinsky's hypothesis of mobility transition (1971) argues that migration is part of the economic and social changes inherent in the modernisation process. It is part of the wider range of functionalist theories of social change and development, which try to link theories to past empirical trends. He argues that patterns and rates of migration can be closely linked to the stage of modernisation (e.g. industrialisation) and demographic factors (e.g. high birth rates). He emphasizes that the preference for more personal freedom is part of the modernisations process. While his theories broadly make sense when looking at past migration patterns in industrialised nations, it is vague and does not allow differentiation of different types of migration and it does not consider the individual migration decisions. This decision is the starting $\mathrm{p} 4$

\section{Micro-theories of migration}

Lee (1966) was the first to formulate migration in a push-pull framework on an individual level, looking at both the supply and demand side of migration. Positive and negative factors at the origin and destination push and pull migrants towards (non) migration, hindered by intervening factors, e.g. migration laws and affected by personal factors, e.g. how the migrant perceives the factors. He makes a number of predictions, for example that greater diversity among people leads to more migration and for this reason there are high rates of migration within the United States. This theory is barely a theory, it is more a grouping of factors affecting migration, without considering the exact causal mechanisms. 
The human capital approach is the neoclassical micro-level migration theory. Based on the work of Sjaastad (1962) migration is treated as an individual investment decision to increase the productivity of human capital, thus again focusing on the labour market, but at the same time explaining the selectivity of heterogeneous migrants. Individuals make a rational cost-benefit calculation of the expected discounted returns of migration over future time periods, migrating only when the expected returns are positive. The formula below is one of the many variations that is used to model this approach.

$$
E R(0)=\int_{0}^{n}\left[p_{D}(t) p_{E D}(t) Y_{D}(t) N R_{D}(t)-p_{E O}(t) Y_{O}(t) N R_{O}(t)\right] e^{-r t} d t-C(0)
$$

The expected returns depend on the expected benefits and migration costs. Migration costs $\mathrm{C}$ consist of the monetary travel costs and non-monetary opportunity costs and psycological costs. The expected benefits consist of the discounted earnings (dependant on income at the destination $\mathrm{Y}_{\mathrm{D}}$ and origin $\mathrm{Y}_{\mathrm{O}}$, respective employment probabilities $\mathrm{p}_{\mathrm{ED}}$ and $\mathrm{p}_{\mathrm{EO}}$ and the deportation probability $\mathrm{p}_{\mathrm{D}}$ ) and non-monetary returns (NR), e.g. a preference for the new location. The theory emphasizes that migration might lead to occupational upgrading (i.e. investment in human capital of the migrant). Age of the migrants obviously plays a significant factor here, therefore the expected returns are discounted over the remaining lifetime. This model predicts that the young and educated migrate in the first phase. In the basic model information is freely available. The model can easily be criticised on unrealistic assumptions. Fischer, Martin \& Straubhaar (1997) therefore propose a more advanced version of the model, where the no risk and asymmetric information assumptions are dropped. The human capital approach is interesting and useful in explaining the selectivity of migrants, but it is very hard to test empirically. It also ignores more structural influencing factors.

Wolpert's stress-threshold model (1965) describes a behavioural model of internal migration, similar to a cost-benefit analysis, but assuming individuals that intend to be rational ex-ante, but are not necessarily so ex-post. Individuals have a threshold level of utility they aspire to. They compare place utilities to this threshold in order to decide whether to migrate or not and to which place. Place utilities for the current position are based on past and future rewards, whereas place utilities for possible destinations depend on anticipated rewards. Knowledge is based on the subjective and 
incomplete knowledge that individuals have in their personal action spaces, so rationality is bounded. Action spaces depend on personal characteristics, the variability of the environment and life-stage of the individual. Migration flows thus occur as a consequence of these individual place utility evaluations and are not necessarily optimal according to rational and perfect information standards. This model leaves out some of the unrealistic assumptions of the human capital approach, but it is even more difficult to test. In a way Wolpert only changes the terminology, compared to the human capital approach.

Another behavioural model, the value-expectancy model (Crawford, 1973) is a cognitive model in which migrants make a conscious decision to migrate based on more than economic considerations. The potential migrant's strength of migration intentions depends on a multiplication of the values of migration outcomes and expectations that migration will actually lead to these outcomes. Values are specific goals, e.g. wealth or autonomy. Values and expectations depend on personal and household characteristics (e.g. education level) and societal norms. These values do not necessarily need to be economic, for example security or self-fulfilment can also be important to potential migrants. Migration depends on the strength of migration intentions, indirect influences of individual and societal factors and modifying effects of constraints and facilitators. It is similar to the place-utility approach of Wolpert and again it shows that migration choices are subjectively made. There are also other similar micro-based individual behavioural decision making models, e.g. work by de Jong \& Fawcett (1981) or the adjustment-to-stress approach of Ritchey (1976). The behavioural approach also considers non-economic factors and societal influences, but it is very vague and rational decision making is still assumed.

Complimentary to the dual labour market theory is Hoffmann-Novotny's approach of explaining migrations as a theory of social systems (Hoffmann-Novotny, 1981). According to this theory migration is a result of resolving structural tensions (power questions) and anominal tensions (prestige questions). Migrants hope to achieve their desired status in the destination country, but often tensions are transformed instead of reduced. How successful they are depends on the global distributions of the different systems (for the different countries) among "status lines". A migrant coming from a country with a low rank is unlikely to achieve a high internal rank at the destination. "Undercasting" of migrants takes place, which means that migrants take on the lowest 
position in society, whereas lower stratum natives experience upward mobility, at least in terms of power/ income. This theory does not exclude economic push factors for migration, but instead places them in a wider context of other societal push factors and also considers what happens to migrants at their destination. The theory broadly makes sense and furthermore includes structural factors, which most micro theories neglect. It is not easy to apply and test it however.

\section{Family-decision making and the New Economics of Labour Migration}

The more traditional migration approaches focus either on aggregate migration movements or individuals making migration decisions. They thus assume that individuals independently make the decision to migrate. Some of the migration literature includes a seemingly wider decision-making framework, for example Harbison (1981) paper is entitled "Family Structure and Family Strategy in Migration Decision Making". However, the migration decision is still not seen as a strategic family decision; the paper only acknowledges that families can influence the individual migrant's decision, e.g. through the demographic structure. When looking at migration from a gender perspective, family structure can influence the migration decisions of women in particular. As Morokvasic (1984) points out, women migrate not only because of economic motives, but also to get married, due to social constraints, low rights and lack of protection against domestic violence.

Sandell (1977) and Mincer (1978) on the other hand view migration as a family decision. The family as a whole migrates if their net gain is positive. If only one partner finds a (better) job at the destination, the family only migrates if gains of one family member internalise the losses of the other family member. The family migration decision is thus in essence an aggregation of individual migration utilities. Bigsten (1988) also considers migration a household decision in which a family allocates labour to the urban or rural sector depending on the marginal products of combined wages.

The New Economics of Labour Migration (NELM) goes one step further. According to this approach decisions are often made by household members together and for the wellbeing of the family as a whole ${ }^{1}$. Households also do not migrate together (as in Mincer, for example), but rather send of one or more household members off as

\footnotetext{
${ }^{1}$ This does not exclude having individual household members benefiting from the migration decision taken.
} 
migrants. The NELM is a fundamentally different theory of migration that was developed by Oded Stark in the 1980s, in cooperation with David Bloom, Eliakim Katz, David Levhari, Robert Lucas, Mark Rosenzweig, and J. Edward Taylor. The NELM is the only migration theory that explicitly links the migration decision to the impacts of migration, with remittances being this link (Taylor \& Fletcher, 2001). According to the NELM a household maximises joint income, status and minimises risks. All three aspects contribute to the migration decision of the household. Each of those will now be discussed in turn.

Referring to the classical migration approaches the NELM acknowledges that potentially earning higher incomes matter to potential migrants, while adding that relative income (or accordingly relative deprivation) of the household also matters. "In real life it is likely that migration decisions are influenced by both absolute and relative income considerations" (Stark, 1991, p. 145). Relative income can be seen as social "status", assessed in comparison to the reference group of the household. The reference group can be the local community, village, town etc. Status is not only of intrinsic value, but it might also translate into monetary benefits, for example in LDCs money-lenders often lend money with implicit social status as the collateral.

A household then gains twofold from having a household member abroad to a place with higher income: In terms of a higher absolute income and in terms of a higher relative income. Both factors lead to the hypothesis that a household at the lower end of the income distribution is more likely to migrate. Stark (1991) points out that this prediction might not hold for the most deprived households, since bare survival is more urgent for them and they might not be able to afford migration. He also notes that absolute and relative income effects tend to move in the same direction, so they will be difficult to separate. Comparing two villages, where one village has a more unequal income distribution, a household with a certain income might migrate in the village with the unequal income distribution, but not in the other one with a more condensed income distribution, because there the household is relatively better off. Subsequently villages with a more unequal income distribution will experience higher overall migration.

The other major contribution of NELM is the consideration of risks. These risks are mainly linked to capital market failures in the source areas, other than labour market 
failures already analysed by other authors, e.g. Todaro. ${ }^{2}$ Household try to overcome market failures in their environment, for example missing or incomplete credit and insurance markets. If public social protection is also limited, the household has no means to smooth consumption in difficult times or to make investments. As will be argued below, migration is a way of overcoming these market failures. The first assumption is that households are influenced by both the mean and variability (i.e. risk) of income. The NELM can be linked to the broader risks and poverty literature (see for example Dercon, 2005), where migration is one of the strategies that poor households pursue in an environment of risks and missing markets. ${ }^{3}$

The basic argument in the migration context (based on Stark \& Levhari, 1982) is as follows: An optimising, risk-averse household in a LDC wants to introduce a new technology that increases the expected return from agriculture but at the same time also increases the subjective risk. Since there are no insurance or credit markets, the household has to solve this problem internally. In order to lower the risks associated with the new technology, the households wants to spread the risk by diversifying its income portfolio. In rural areas of LDC non-farm activities are often not available or too closely correlated to farm activities. Therefore the household chooses another strategy, namely sending a family member to the non-correlated or negatively correlated urban labour market. ${ }^{4}$

The migration costs are shared between household members and there is household coinsurance: The migrant is supported by the family in times of need (e.g. urban unemployment) and the migrant sends home remittances to the family for their consumption smoothing and investment activities (e.g. by financing new production techniques, investing in businesses, shelter). This arrangement is possible due to a different time profile of risks (first the migrant is supported until a job has been found,

\footnotetext{
${ }^{2}$ Capital market failures can lead to disequilibria in other markets, for example the labour market. A low capital level in rural areas can lead to a low marginal product of labour, i.e. low rural wages and high migration to urban areas. This looks like evidence for Todaro type migration thesis, but is actually caused by capital market failures (Morrison, 1994).

${ }^{3}$ The NELM theory is also related to the sustainable livelihoods literature, where migration is also seen as one possible option of having a sustainable livelihood (improving/ avoiding deterioration of household poverty, wellbeing, capabilities, resilience and natural resource base (De Haan et al., 2002). In the sustainable livelihoods literature the alternatives activities (besides the broad category agriculture of the NELM) are made more concrete and it tries to make the interaction between the impact of migration on the other livelihood strategies more clear.

${ }^{4}$ Stark $(1982,1986)$ also shows the case of a risk-averse individual: Such an individual, having an inter-temporal utility function, might migrate despite higher short-term risks, because medium-term risks are lower.
} 
then the household receives remittances to make the investment). Due to coinsurance, each party is able to participate in temporarily risky behaviour. Of course it should not be forgotten that both the family back home and the migrant face uncertainty about the expected returns of their activities (Taylor, 1986). Not only rural activities are subject to uncertainty (e.g. agricultural prices, pests), but also the activities of migrants (e.g. finding a job). That is precisely why the coinsurance and diversification of income sources is so useful.

In order for such a cooperative equilibrium to be possible, households either have to have a powerful household head that can enforce the contract, altruism has to be present in the household or cooperation is a dominant strategy of all household members. Other reasons why these contracts can be self-enforcing are: Unstable urban labour markets, strong identification of the migrant with village of origin, bequest motive, repaying education costs, tight rural insurance markets, strong dependence of investments for new technology (Stark \& Lucas, 1988), surveillance of the migrant at the destination, cultural conventions etc.

The family context is thus crucial in determining whether such a contract is successful or not. The voluntary, implicit contract between household members is based on mutual interdependence; it is a cooperative game, whose outcome depends on the bargaining power of different household members ${ }^{5}$. Foster and Rosenzweig (2001) show that the higher the altruism between the parties and the lower the income correlation, the more likely risk-sharing is likely to occur. Transfers are also conditioned by past transfers, so transfers should flow in both directions for coinsurance to work well. The contract is designed to be self-enforcing, also including devices to handle principal-agent and moral hazard problems. ${ }^{6}$

In conclusion, if income and or status are low and or risks are high and there are market and government failures (so no other means of social protection), the household then makes the decision that one or more members of the household migrates to a labour market that is negatively or non-correlated with the local labour market. They thus co-insure each other by diversifying their labour portfolio. Both the

\footnotetext{
${ }^{5}$ For example the household has a higher bargaining power over the migrant (i.e. gets more remittances) if there is high urban unemployment (i.e. the migrant is more dependent on the family).

${ }^{6}$ Guilmoto \& Sandron (2001) also argue that institutionalization of migration and inter-temporal transactions occur as a result of weak and imperfect markets. Migrants develop their own institutions (rules, norms etc) that regulate exchanges in order to decrease transaction and information costs.
} 
diversification of income and the investment-enabling character of remittances matter to the migration strategy. Households cooperate to achieve the income diversification and informal insurance and also benefit from intra-household specialisation (migrants/ non migrants). Finally, the NELM should not be seen in isolation of the other migration theories. Stark includes the income differential approach to migration. Taylor (1986) points out that migration networks can be a source of information, thus increasing the certainty about returns in potential migration destinations.

The NELM extends the migration decision to also include risk and insurance considerations, household decision making and links the migration causes to the consequences. Therefore it is a more realistic and useful theory, even though it is still quite abstract and stylised and has some strong assumptions, like rationality. Unlike the sustainable livelihoods literature it is also quite vague on the combination of different types of activities. Like most theories of migration it is also vague about how migrants choose where to go specifically.

\section{Perpetuation of migration}

As Massey (1990) argues the factors that influence migration to start could be very different from the conditions that make migration continue, i.e. perpetuate. After an initial phase of pioneer migration, migration becomes more common in the community, with more and more people imitating current migrants and being helped by them until migration becomes self-sustaining. There are different aspects of the perpetuation of migration, including social capital, social networks, migration institutions and cumulative and circular migration and they are discussed below.

Thomas Faist, a sociologist, emphasizes the meso-level of migration (1997, 2000). By studying the meso-level, he links the rational individual migration decision models to the structural macro migration models. Social relations and social capital in households, neighbourhoods, communities and more formal organisations help migrants in the migration decision and adaptation process, so they are both a resource and an integrating device. Different social relations imply different social capital and obligations and outcomes, for example exchange relationships (e.g. between migrant and migration-brokers) are based on weak social ties and usually do not imply solidarity or reciprocity between the parties involved. Social capital can be seen as a resource that is acquired as a result of different kinds of relationship (Bordieu \& 
Wacquant (1992) in Massey et al. (1998)) and can be converted into other types of capital (e.g. borrowing money for migration from your neighbour). Through the use of concepts like social relations or social capital the mechanism with which macrofactors shape micro-decision making is made clearer. One example of social ties and social capital in practice is the network theory, discussed below.

The role of social linkages and especially migrant networks on the micro or meso level is crucial for understanding the patterns and volume of the migration, once it has set off. After a pioneer period, where migrants face many difficulties, the access of their followers to the destination country is easier, as they are better informed through the pioneer migrants. New channels of communication are established and communities of migrants are created in a receiving country (Goss \& Lindquist 1995). New migrants will receive help from the pioneer migrants ranging from arranging the trip to finding a job, thus making migration increasingly cost and risk free. Empirical applications of networks can be found all over the world, maybe being one of the most visible aspects of migration theory.

According to Guilomoto \& Sandron (2001) migrant networks perpetuate themselves due to institutionalisation, path dependency etc., but are also affected by external factors e.g. labour market changes. The institutional part of a network refers to the rules and norms governing the network that reduce the transaction and migration costs (e.g. children sending home remittances to their parents), whereas the organisational aspects refer to the practical help given to pioneers within the network. As mentioned above, networks depend on path dependency and are not necessarily the most efficient solution; a chance event happening to a pioneer can shape the entire network. Networks can be both a chance and threat to a potential migrant. Migrant networks are held in place by these institutionalised norms, also known as social capital, but they are complimented with external migrant institutions (Goss \& Lindquist 1995). These institutions, ranging from people smugglers to recruiting agents and humanitarian NGOs, also help to perpetuate the flows of migration.

As argued above, migration networks decrease the costs and risks of migration over time and thus make migration more likely and widespread in a community, the more people have migrated. Stark and Wang (2002) argue that one reason why the more highly educated pioneers help new migrants is that having less-skilled migrants in the 
destination country helps to differentiate their own skills better. Other reasons could be altruism, patriotism or ownership of relevant social capital.

A final meso-level theory of migration is cumulative and circular causation (Massey (1990)), which shows how migration becomes more and more common since it has started, by sustaining itself. Past migration alters the context in which current migration decisions are made by changing the socio-economic context and macro environment of migrant households that then affect the migration decisions of future migrants. Networks expand, migration becomes part of local culture and make migration more and more accessible to all levels of the population. There is likely to be lower labour demand in the areas of origin due to new, less labour-intensive agricultural production methods brought home by migrants and land left empty by migrants. If more educated people leave, the source regions stagnate, increasing the returns from migration. Finally migration can change the local income distribution, again increasing the returns from migration. Thus, according to this theory, the more migration there is, the more migration there may be in the future. Of course migration does not continue indefinitely: At one point migration networks become saturated, labour scarcity in the source country increases and migration potential is very low with only old people or children left to migrate. At this stage migration might start to a decrease which makes the overall migration curve inverted $\mathrm{u}$-shaped.

\section{A general framework of migration decision making}

The above review summarised the most important economic migration theories. Comparing and contrasting them makes it clear that they are not necessarily conflicting, but that they can be combined in a complimentary fashion. Individual decisions are made in specific social context that feed back into the economic and social structural environment and affect future migration choices (Massey et al. (1994)). Figure 1 below shows the links the different theories and sums them up into one complete picture.

It is clear that most migrants do not take the decision to migrate in a social vacuum and that their family is likely to have some influence. Therefore the migration decision should be considered on a household level. The migration decision entails weighing up the costs versus the benefits of migration. Various factors are likely to affect the costs and benefits. 
Figure 1. A general framework of migration decision making

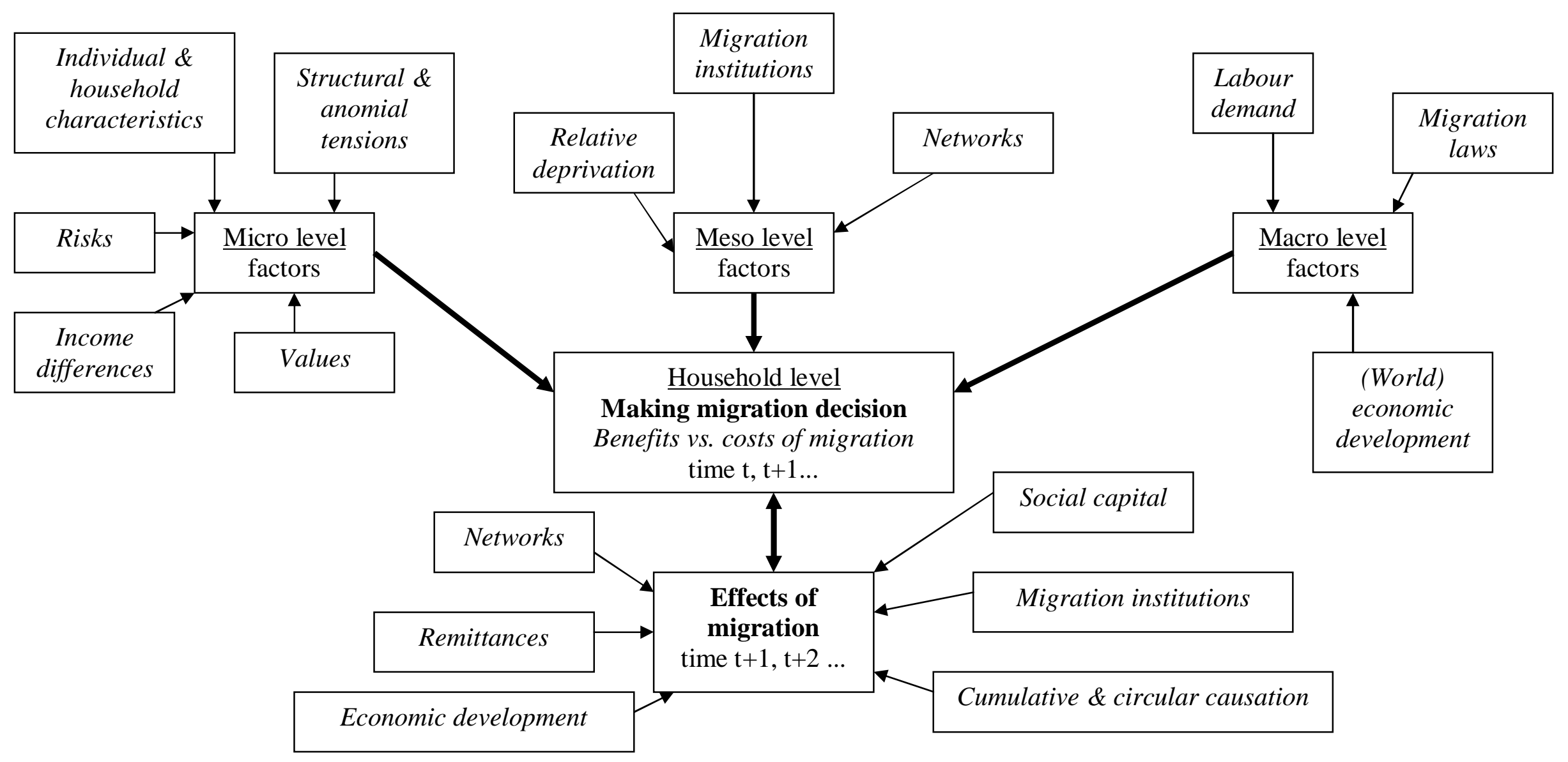

Source: Own compilation 
On the micro-level income differences and poverty undoubtedly push and pull potential migrants. Risks and dysfunctional credit markets in the home country could also be reasons for migration. Questions of power and prestige can also influence decision making, as well as other personal goals or values. Furthermore personal and household characteristics (e.g. marital status, education level) are very important in explaining the selectivity of migrants.

Looking at the meso level, migration is more likely to take place in a context of relative deprivation, i.e. in a community with higher levels of inequality. Migration is also more likely to take place if migration institutions have already been established or if migrant networks are available to the potential migrant.

On the macro-level the demand for labour and migration laws are crucial in influencing the decision to migrate, but especially the destination of migrants. Globalisation and world-wide economic development may affect migration flows in many ways ranging from decreasing transportation costs to changing job prospects all over the world.

Finally, migration has many effects that in turn also influence the decision-making process of future migrants. Migration affects economic development in the origin and destination country and therefore changes potential pull and pull factors. For example high migration flows, might make labour scarce in the origin community and therefore improves the job prospects of people left behind. These people are less likely to migrate, as the benefits of migration are lower. Cumulative and circular migration refers to the fact that once migration is in place, it sustains itself. It has been shown that migrant institutions, social capital and networks that develop over time as more people migrate, reduce the costs and ease of migration for future migrants. Migrants send remittances home that might finance the migration costs of future migrants.

\section{Conclusion}

The synthesis in the previous section showed the complementarities between the different migration theories. Very broadly, the migration decision entails weighing the costs versus the benefits of migration. The importance of wage differentials or income consideration, emphasized by the neoclassical approaches, is taken for granted by most theories and it is considered a necessary condition for people to migrate. Other 
more sociological factors, like the need for security, coming from the behavioural models, should also be considered. It has also been argued that co-insurance and relative deprivation affect migration decision making as well. It is also clear that a wider decision-making framework on the household level is appropriate, as very few individuals are isolated actors that take decisions in a social vacuum.

As the different system theories explain, the different actors are not isolated but often affect one another at one point in time (through social capital) and over time (e.g. cumulative causation). It is therefore important to consider the different levels of migration. Structural macro factors affect the decisions made on the micro level. Political institutions (e.g. migration laws), pull factors (like labour demand in the Dual-Labour Market theory), economic development (like in the World Systems theory, NELM or mobility of transition) all constrain the migrant's decision making progress. On a meso level social capital, institutions and networks can help or hinder migration.

Finally, migration should not be considered cross-sectionally, but historically over time. Migration is dynamic. The NELM makes it clear that the causes and consequences of migration are linked. As the cumulative causation theory shows, migration trends and migrant characteristics can change depending on the stage of migration. Current migrants can affect the structural environment, e.g. through influencing economic development in the origin country. Due to the dynamic nature of migration, the question of why people migrate will continue to be a lively and interesting topic in the years to come. 


\section{References}

Bigsten, A. (1988). "A Note on the Modelling of Circular Smallholder Migration." Economics Letters 28: 87-91.

Bordieu, P., \& Wacquant, L. (1992). Invitation to Reflexive Sociology. Chicago: Chicago University Press.

Boyle, P., K. Halfacre, et al. (1998). Chapter 3: Contrasting conceptual approaches in migration research. Exploring contemporary migration. Harlow, Longman.

Crawford, T. (1973). Beliefs About Birth Control: A Consistency Theory Analysis. Representative Research in Social Psychology, 4, 53-65.

Dercon, S. (2005). Insurance Against Poverty. Oxford, Oxford University Press.

Faist, T. (1997). The Crucial Meso-Level. International Migration, Immobility and Development. T. Hammer, G. Brochmann, K. Tamas and T. Faist. Oxford, Berg Publishers

Faist, T. (2000). The Volume and Dynamics of International Migration and Transnational Social Spaces. Oxford, Clarendon Press.

Fischer, P. A., R. Martin, et al. (1997). Should I Stay or Should I Go? International Migration, Immobility and Development. T. Hammer, G. Brochmann, K. Tamas and T. Faist. Oxford, Berg Publishers

Foster, A. D. and M. R. Rosenzweig (2001). "Imperfect Commitment, Altruism, and the Family: Evidence from Transfer Behaviour in Low-Income Rural Areas." The Review of Economics and Statistics 83(3): 389-407.

Goss, J. and B. Lindquist (1995). "Conceptualizing International Labour Migration: A Structuration Perspective." International Migration Review 29(2): 317-351.

Guilmoto, C. Z. and F. Sandron (2001). "The Internal Dynamics of Migration Networks in Developing Countries." Population: An English Selection 13(2): 135164.

Haan, A. d., Brock, K., \& Coulibaly, N. (2002). Migration, livelihoods and institutions: contrasting patterns of migration in Mali. Labour Mobility and Rural Society, 38(5), 37-58.

Harbison, S. F. (1981). Family Structure and Family Strategy in Migration Decision Making. Migration Decision Making. G. d. Jong and R. Gardner. New York, Pergamon Press.

Harris, J. and M. Todaro (1970). "Migration, Unemployment and Development: A Two-Sector Analysis." The American Economic Review 60: 126-142.

Haug, S. (2000). "Klassischere und neuere Theorien der Migration (Classical and newer theories of migration)." Arbeitspapiere- Mannheimer Zentrum fuer Europaeische Sozialforschung(30).

Hoffmann-Nowotny, H.-J. (1981). A Sociological Approach Toward a General Theory of Migration. Global Trends in Migration. M. Kritz, L. L. Lim and H. Zlotnik. New York, Centre for Migration Studies.

Hollifield, J. F. (2000). The Politics of International Migration. Migration Theory Talking Across Disciplines. C. B. Brettell and J. F. Hollifield. New York, Routledge. 
Jong, G. D. and J. Fawcett (1981). Motivations for Migration: An Assessment and a Value-Expectancy Model. Migration Decision Making. G. D. Jong and R. Gardner. New York, Pergamon Press.

Kritz, M. M. and H. Zlotnik (1992). Global Interactions: Migration Systems, Processes, and Policies. International Migration Systems A Global Approach. M. Kritz, L. L. Lim and H. Zlotnik. Oxford, Clarendon Press.

Lall, S., H. Selod, et al. (2006). "Rural-Urban Migration in Developing Countries: A Survey of Theoretical Predictions and Empirical Findings." World Bank Policy Research Working Paper(3915).

Lee, E. (1966). "A Theory of Migration." Demography 3(1): 47-57.

Lewis, W. A. (1954). Economic Development with Unlimited Supply of Labour. The Manchester School, 22(2), 139-191.

Mabogunje, A. L. (1970). "Systems Approach to a Theory of Rural-Urban Migration." Geographical Analysis 2: 1-18.

Massey, D. (1999). Why Does Immigration Occur? A Theoretical Synthesis. The handbook of international migration : the American experience C. Hirschman, P. Kasinitz and J. DeWind. New York, Russell Sage Foundation.

Massey, D., J. Arango, et al. (1994). "Theories of International Migration: A Review and Appraisal." Population and Development Review 19(3).

Massey, D. S. (1990). "Social Structure, Household Strategies, and the Cumulative Causation of Migration." Population Index 56(1): 3-26.

Massey, D. S., J. Arango, et al. (1998). Worlds in Motion. Oxford, Clarendon Press.

McDowell, C. and A. d. Haan (1997). "Migration and sustainable livelyhoods: a critical review of the literature." IDS Working Paper(65).

Mincer, J. (1978). "Family Migration Decisions." Journal of Political Economy 86(5): 749-773.

Mora, J. and J. E. Taylor (2005). Determinants of Migration, Destination, and Sector Choice: Disentangling Individual, Household, and Community Effects. International Migration, Remittances, and the Brain Drain M. Schiff and Ç. Özden, Palgrave Macmillan

Morokvasic, M. (1984). "Birds of Passage are also Women." International Migration Review 18(4): 886-907.

Morrison, A. R. (1994). "Capital Market Imperfections, Labor Market Disequilbrium and Migration: A Theoretical and Empirical Analysis." Economic Inquiry 32(2): 290302.

Piore, M. J. (1979). Birds of passage: migrant labor and industrial societies: Cambridge University Press.

Stark, O., \& Lucas, R. E. B. (1988). Migration, Remittances, and the Family. Economic Development and Cultural Change, 36(3), 465-481.

Ritchey, P. N. (1976). "Explanations of Migration." Annual Review of Sociology 2: 363-404. 
Ranis, G., \& Fei, J. C. H. (1961). A Theory of Economic Development. The American Economic Review, 51(4), 533-565.

Ravenstein, E. G. (1885). The Laws of Migration. Journal of the Statistical Society of London, 48(2), 167-235.

Rosenzweig, M. R. (1988). "Risk, Implicit Contracts and the Family in Rural Areas of Low-Income Countries." The Economic Journal 98(December 1988): 1148-1170.

Sandell, S. H. (1977). Women and the Economics of Family Migration. The Review of Economics and Statistics, 59(4), 406-414.

Sjaastad, L. (1962). "The Costs and Returns of Human Migration." Journal of Political Economy 70(5): 80-93.

Stark, O. (1984). "Migration Decision Making: A Review Article." Journal of Development Economics 14: 251-259.

Stark, O. (1991). The Migration of Labour. Oxford, Blackwell Publishers.

Stark, O. and D. E. Bloom (1985). "The New Economics of Labour Migration." American Economic Review 75: 173-178.

Stark, O. and D. Levhari (1982). "On Migration and Risk in LDCs." Economic Development and Cultural Change 31(1): 191-196.

Stark, O. and W. Q. Wang (2002). "Migration dynamics." Economics Letters 76: 159164.

Taylor, J. E. (1999). "The New Economics of Labour Migration and the Role of Remittances in the Migration Process." International Migration 37(1).

Taylor, J. E. (2001). Migration: new dimensions and characteristics, causes, consequences and implications for rural poverty. Food, Agriculture and Rural Development. K. G. Stamoulis. Rome, Food and Agricultural Organisation.

Taylor, J. E. and P. L. Fletcher (2001). "Remittances and Development in Mexico: The New Labour Economics of Migration: a Critical Review." Rural Mexico Research Project 2.

Taylor, J. E. and P. L. Martin (2001). Human Capital: Migration and Rural Population Change. Handbook of Agricultural Economic. B. Gardner and G. Rausser. Amsterdam, Elsevier Science. 1.

Todaro, M. (1969). "A Model of Labor Migration and Urban Unemployment in Less Developed Countries." The American Economic Review 59(March 1969): 138-148.

Wallerstein, I. (1974). The Modern World-system: Academic Press New York.

Wolpert, J. (1965). "Behavioural Aspects of the Decision to Migrate." Papers of the Regional Science Association 15: 159-169.

Zelinsky, W. (1971). "The Hypothesis of the Mobility Transition." Geographical Review 61(2): 219-249.

Zipf, G. (1946). The PP/D hypothesis: on the Intercity Movement of Persons. American Sociological Review, 11, 677-686.

Zolberg, A. (1981). International Migration in Political Perspective. Global Trends in Migration. M. Kritz, L. L. Lim and H. Zlotnik. New York, Centre for Migration Studies. 


\section{Maastricht Graduate School of Governance Working Paper Series}

\section{List of publications}

\begin{tabular}{|c|c|c|}
\hline $\begin{array}{l}2006 \\
\text { No. }\end{array}$ & Author(s) & Title \\
\hline 001 & $\begin{array}{l}\text { Gassmann, F. and } \\
\text { G. Notten }\end{array}$ & $\begin{array}{l}\text { Size matters: Poverty reduction effects of means-tested and } \\
\text { universal child benefits in Russia }\end{array}$ \\
\hline 002 & $\begin{array}{l}\text { Hagen-Zanker, J. } \\
\text { and } \\
\text { M.R. Muñiz Castillo }\end{array}$ & $\begin{array}{l}\text { Exploring multi-dimensional wellbeing and remittances in } \\
\text { El Salvador }\end{array}$ \\
\hline 003 & Augsburg, B. & $\begin{array}{l}\text { Econometric evaluation of the SEWA Bank in India: } \\
\text { Applying matching techniques based on the propensity } \\
\text { score }\end{array}$ \\
\hline 004 & $\begin{array}{l}\text { Notten, G. and } \\
\text { D. de Crombrugghe ( }\end{array}$ & Poverty and consumption smoothing in Russia \\
\hline
\end{tabular}

\begin{tabular}{|c|c|c|}
\hline No. & Author $(s)$ & Title \\
\hline 001 & $\begin{array}{l}\text { Notten, G. and C. de } \\
\text { Neubourg }\end{array}$ & $\begin{array}{l}\text { Relative or absolute poverty in the US and EU? The battle } \\
\text { of the rates }\end{array}$ \\
\hline 002 & $\begin{array}{l}\text { Hodges, A. A. } \\
\text { Dufay, K. Dashdorj, } \\
\text { K.Y. Jong, T. } \\
\text { Mungun and U. } \\
\text { Budragchaa }\end{array}$ & $\begin{array}{l}\text { Child benefits and poverty reduction: Evidence from } \\
\text { Mongolia's Child Money Programme }\end{array}$ \\
\hline 003 & $\begin{array}{l}\text { Hagen-Zanker, J. } \\
\text { and Siegel, M. }\end{array}$ & The determinants of remittances: A review of the literature \\
\hline 004 & Notten, G. & $\begin{array}{l}\text { Managing risks: What Russian households do to smooth } \\
\text { consumption }\end{array}$ \\
\hline 005 & $\begin{array}{l}\text { Notten, G. and C. de } \\
\text { Neubourg }\end{array}$ & $\begin{array}{l}\text { Poverty in Europe and the USA: Exchanging official } \\
\text { measurement methods }\end{array}$ \\
\hline 006 & $\begin{array}{l}\text { Notten, G and C. de } \\
\text { Neubourg }\end{array}$ & $\begin{array}{l}\text { The policy relevance of absolute and relative poverty } \\
\text { headcounts: Whats in a number? }\end{array}$ \\
\hline 007 & $\begin{array}{l}\text { Hagen-Zanker, J. } \\
\text { and M. Siegel }\end{array}$ & $\begin{array}{l}\text { A critical discussion of the motivation to remit in Albania } \\
\text { and Moldova }\end{array}$ \\
\hline 008 & Wu, Treena & $\begin{array}{l}\text { Types of Households most vulnerable to physical and } \\
\text { economic threats: Case studies in Aceh after the Tsunami } \\
\text { (Theme 2) }\end{array}$ \\
\hline 009 & Siegel, $M$. & Immigrant Integration and Remittance Channel Choice \\
\hline
\end{tabular}

\section{8}

\begin{tabular}{lll} 
No. & Author $(s)$ & Title \\
\hline 001 & $\begin{array}{l}\text { Roelen, } \text { K. and } \\
\text { Gassmann, } F .\end{array}$ & $\begin{array}{l}\text { Measuring Child Poverty and Well-Being: a literature } \\
\text { review }\end{array}$ \\
\hline 002 & Hagen-Zanker, J. & $\begin{array}{l}\text { Why do people migrate? A review of the theoretical } \\
\text { literature }\end{array}$
\end{tabular}

